\title{
Como Ler e Entender a História - Parte 2
}

\section{How to Read and Understand History ${ }^{1}$}

\author{
Trabalho Original: \\ RUSSELL, Bertrand. Understanding History. And Other Essays. New York: Wisdom Library/Philosophical \\ Library, 1957. Páginas 9 a 56.
}

Tradutor:

\section{Ernane São João Garcia}

Graduando em Filosofia pela Universidade Federal de São Carlos (UFSCar), São Carlos-SP, Brasil. COPYRIGHT 1957 BY PHILOSOPHICAL LIBRARY, INC. Permissão para publicação conferida pela editora.

Errata: Na página 8 da primeira parte desta tradução, na penúltima linha do segundo parágrafo, onde se lê "para todos os seus defeitos", leia-se "apesar de todos os seus defeitos". (N. T.)

\section{Nota do tradutor}

Apesar de Russell admitir não ser um historiador profissional - cf. a primeira parte desta tradução no Volume anterior -, Egner e Dennon estão certos em afirmar que o filósofo inglês apresenta insights penetrantes de alguns dos problemas cruciais da história. ${ }^{2}$ Esperamos contribuir, assim, para que a tradução dos seus escritos de filosofia da história, embora um dos elementos menos estudados de sua extensa obra, preencha as lacunas da bibliografia russeliana em língua portuguesa.

Para Russell, a importância da história, que não deve ser um interesse apenas de estudiosos acadêmicos, mas "um componente essencial de qualquer mente educada", 3 pode ser apreendida nas linhas iniciais de um ensaio publicado quase quarenta anos antes: "De todos os estudos pelos quais os homens adquirem a cidadania intelectual, nenhum é tão indispensável quanto o estudo do passado". ${ }^{4}$ Russell conservou este fascínio pela história até sua morte, lúcida, aos 97 anos: sua própria vida foi um testemunhar incessante de acontecimentos históricos.

\footnotetext{
${ }^{1}$ COPYRIGHT 1957 BY PHILOSOPHICAL LIBRARY, INC. Permissão para publicação conferida pela editora.

${ }^{2}$ EGNER, Robert E.; DENNON, Lester E. (org.). In: RUSSELL, Bertrand. The basic writings of Bertrand Russell. Nova York: Routledge, 2009. p. 498. (N. T.)

${ }^{3}$ RUSSELL, B. Portraits From Memory. Nova Iorque: Simon \& Schuster, 1956. p. 196. Tradução nossa. (N. T.)

${ }^{4}$ RUSSELL, B. On history. The Independent Review, Londres, v 3, p. 207-215, 1904. Tradução nossa. O ensaio traduzido neste Volume foi publicado em 1943. (N. T.)
} 
Utilizamos as traduções de Millôr Fernandes, Carlos Alberto Nunes e Beatriz Viégas-Faria para os versos de Shakespeare.

\section{Bertrand Russell}

Historiadores da economia, deve-se dizer, são um tanto afeitos a estereótipos. Quase todo livro de história econômica, não importam o território e a época abordados, conterá certas páginas de lamentação com a seguinte feição: “Neste período o antigo campônio ${ }^{5}$ estava entrando em decadência; a terra foi penhorada para os especuladores avarentos da cidade, aos quais os lavradores tornaram-se atual ou potencialmente escravizados. A velha aristocracia, que, apesar de todos os defeitos, tivera algum senso de responsabilidade pública, estava sendo substituída por uma nova plutocracia, ignara das necessidades da agricultura, e desejosa apenas de extrair o máximo de recursos no menor período de tempo possível. Arruinados e sem bens, os camponeses arribaram para as cidades, onde se tornaram parte da agitação proletária, e uma massa manobrável segundo as conspirações dos demagogos. As humildes fés antigas declinaram, para serem substituídas por ceticismo e violência." Você vai encontrar isto, ou coisa parecida, na história da Grécia em qualquer período a partir do de Hesíodo em diante; de novo em descrições da Itália depois das Guerras Púnicas; novamente em histórias da Inglaterra sob os Tudors. Atualmente os escritores são mais prolixos; o mesmo tipo de narrativa sobre a Califórnia preenche dois longos livros, "Grapes of Wrath"6 e o "Octopus" de Norris7. O que os historiadores dizem é sem dúvida verdadeiro no que tange principalmente aos males do seu tempo, mas muitas vezes errôneo ao supor que outras épocas hajam sido melhores.

Este ponto de vista é em parte um produto da especialização. Um homem que sabe muito sobre certo período, e pouco sobre o imediatamente anterior, imagina particularmente devido a uma convenção literária bem estabelecida - que os males que ele vê no período com o qual está familiarizado eram inéditos. Na verdade, como consequência de otimismo e más colheitas, em todas as épocas os camponeses foram suscetíveis de cair em dívidas. Homens que emprestam dinheiro tendem a viver nas cidades, já que do contrário também seriam pobres. Em todas as épocas as aristocracias foram propícias a certos vícios, tais como o jogo, o duelo e a ostentação, que as obrigavam a repartir suas terras com novos homens. As humildes fés antigas não eram tão humildes ou piedosas como pretendem os historiadores. Ao longo de toda a Idade Média, barões e autoridades eclesiásticas tomavam emprestado dos judeus, e, quando não conseguiam mais pagar os juros, organizavam um pogrom. No início da Idade Moderna, boa parte do capital tornou-se cristão, e então os pogroms de capitalistas não foram mais tolerados. Descrever esta mudança como um declínio das "humildes fés antigas" é algo um tanto enganador. Ela teve, ao contrário, o importante efeito de pôr um fim à pena de "usura" (i.e., o juro), uma pena que, conquanto apoiada na autoridade de Aristóteles, deixou de ter efeito tão logo os credores não eram mais judeus em sua maioria. Mas a Alemanha nazista mostrou que ainda é possível reviver o modelo medieval; o programa do partido nazista, como os clérigos medievais, condena os judeus e os juros da mesma forma.

\footnotetext{
${ }^{5}$ Yeomanry é o termo original. Yeomanry, ou yeoman, refere-se ao pequeno proprietário de terras da Inglaterra no final da Idade Média. (N. T.)

${ }^{6}$ The Grapes of Wrath (1939), obra do escritor norte-americano John Steinbeck, Prêmio Nobel de Literatura em 1962. A leitura do livro de Steinbeck parece datar do período em que Bertrand Russell lecionou na Universidade da Califórnia, em 1939. (N. T.)

${ }^{7}$ Frank Norris, autor de The Octopus: A Story of California (1901). (N. T.)
} 
Em um de seus aspectos, a história econômica representa o eterno conflito entre a cidade e o campo. Em todas as épocas a cultura permaneceu predominantemente urbana, e a fé predominantemente rural. Na Antiguidade, quase tudo de valor para a posteridade era urbano. A filosofia e a ciência gregas germinaram nas ricas cidades comerciais da Ásia Menor e da Sicília; só então passaram para Atenas, e daí, finalmente, para Alexandria. Os romanos que lutaram nas Guerras Púnicas eram em sua maior parte agricultores, e tinham muito pouca cultura. Mas depois que a vitória enriquecera os romanos, estes deixaram a agricultura para os escravos e nações subjugadas, ao mesmo tempo que se voltavam para a cultura grega e a luxúria oriental. O comércio entre as diferentes partes do Império Romano cresceu rapidamente, atingindo o ponto máximo no século 2 d.C. Grandes cidades floresceram, mesmo em regiões ora desabitadas. Suas ruínas impressionam os turistas nos áridos desertos do Norte da África. Durante todo o longo período que vai de 600 a.C. a 200 d.C., a cidade dominou sobre o campo, o que não foi o caso antes e depois daquelas datas. As mudanças estão refletidas nas concepções religiosas: o Paraíso, no Gênesis, é rural, e assim é o Jardim do Éden de Dante; nos épocas seguintes, as aspirações dos homens estão expressas na República de Platão, na Nova Jerusalém e na Cidade de Deus, todas as quais urbanas.

As invasões bárbaras destruíram as estradas romanas e tornaram as viagens inseguras; em razão disso, quase colocaram um fim ao comércio, e forçaram cada pequeno lote a produzir seu próprio sustento. Ao mesmo tempo, elas fundavam uma aristocracia rural de conquistadores, os quais pouco a pouco desenvolveram o sistema feudal. A cultura laica da Idade Média, exceto na Itália, era rural e aristocrática, não urbana e comercial. Esse elemento rústico sobreviveu na Inglaterra, Alemanha e Rússia até bem recentemente. $\mathrm{O}$ tom da poesia inglesa foi dado pela "lírica selvagem dos bosques nativos" ${ }^{\prime \prime}$ de Shakespeare; Bismarck era um bucólico militante; e Tolstoi considerava toda virtude como ligada à terra. A revolução industrial, porém, fez desse ponto de vista um mero sobrevivente; embora John Bull ${ }^{9}$ seja um fazendeiro, o inglês de hoje é tipicamente urbano.

Nos Estados Unidos, o conflito entre cidade e campo inicia-se com a disputa entre Hamilton e Jefferson; prossegue com Andrew Jackson, que garantiu vitória temporária para a população rural; passando pelo Partido Populista ${ }^{10} \mathrm{e}$ W. J. Bryan, persiste em nossos dias através da luta entre o Farm Bloc ${ }^{11}$ e os anti-inflacionistas. Na Rússia, desde a revolução, o conflito adquiriu formas violentas. A Nova Política Econômica, nos últimos anos de Lênin, foi uma concessão aos camponeses, mas Stalin, por meio de métodos cruéis, finalmente conquistou a vitória para o partido urbano. Tais conflitos são esclarecidos ao serem vistos à luz de sua perspectiva histórica.

As opiniões modernas quanto à relação entre os fatos econômicos e a cultura geral foram profundamente influenciadas pela teoria, exposta pela primeira vez por Marx, segundo a qual o modo de produção de uma era (e em menor grau o modo de troca) é a causa última da configuração de sua política, direito, literatura, filosofia e religião. Como todas as teorias totalizantes, tal doutrina é falsa se aceita como um dogma, mas valiosa se empregada como um meio de sugerir hipóteses. Ela contém uma grande dose de verdade, malgrado não tanto quanto acreditava Marx. "A Religião e o Surgimento do Capitalismo", de R. H. Tawney, um livro de grande

\footnotetext{
${ }^{8}$ Expressão de um verso de John Milton presente no poema bucólico L'Allegro (1645): “Our sweetest Shakespeare, Fancy's child/Warble his native wood-notes wild." (N. T.)

${ }^{9}$ Personagem que representa a cultura nacional inglesa, uma espécie de Tio Sam britânica. (N. T.)

${ }^{10}$ Partido político dos "Populistas", agremiação agrário-populista que perdurou nos Estados Unidos de 1891 a 1908. (N. T.)

${ }^{11}$ Bancada formada por congressistas dos partidos Democrata e Republicano que pressiona o governo federal por políticas favoráveis aos produtores rurais. (N. T.)
} 
interesse e valor, oferece com riqueza de detalhes esclarecedores uma teoria que em certo sentido é o inverso da doutrina de Marx. Tawney está interessado em traçar uma conexão entre o protestantismo e o capitalismo, na qual, em grande parte por meio do individualismo, é o protestantismo a causa e o capitalismo o efeito: o laissezfaire na teologia pode ser considerado a fonte do laissez-faire nos negócios. É inegável que o capitalismo moderno começou nos países protestantes, mas tenho dúvidas se a conexão é realmente o que Tawney representa como sendo.

No século XVII, Inglaterra e Holanda foram as principais nações comerciais. Ambas eram protestantes, e ambas tinham abundantes razões políticas para seu protestantismo. O Papa agraciou Portugal com as Índias Orientais e o Brasil, e a Espanha com o restante do hemisfério ocidental. Isto não agradou a países do norte que desejavam comercializar com a Índia e estabelecer colônias na América. Ademais, a Espanha era uma ameaça para ambas; a Holanda deve sua existência a uma bem-sucedida revolta contra a Espanha, e a Inglaterra deve sua sobrevivência à derrota da Armada Espanhola. O protestantismo foi, naturalmente, hostil à Espanha, a qual era a principal potência católica. Havia, por conseguinte, amplas razões seculares para o protestantismo da Inglaterra e da Holanda. Seu êxito comercial, no entanto, devia-se à superioridade marítima e à posição geográfica. Talvez esse êxito tenha modificado sua religião, que em alguns aspectos distinguia-se no temperamento do luteranismo alemão. Mas duvido se o protestantismo foi, em qualquer medida importante, de fato causa das doutrinas capitalistas que naturalmente eram engendradas pelo comércio e manufaturas. Em época anterior, o norte da Itália deixou o mundo para trás em desenvolvimento econômico, mas não entrou em conflito com o Papa, e não adquiriu o que Tawney considera como a mentalidade protestante. Não nego um elemento de verdade em sua tese, mas penso que tal é menor do que ele supõe.

Voltando a Marx: o erro mais sério em sua teoria, a meu ver, é que ela despreza a inteligência como causa. Homens e macacos, no mesmo ambiente, têm métodos diferentes de assegurar comida: os homens praticam a agricultura, não porque uma dialética sobre-humana os impele a fazê-lo, mas sim porque a inteligência mostra a eles suas vantagens. A revolução industrial poderia ter acontecido na Antiguidade se a inteligência grega tivesse continuado o que ela teve de melhor. A isto é comum responder que o trabalho escravo, sendo barato, removeu o incentivo à invenção de ferramentas para automatizar o trabalho. Os fatos não sustentam esta opinião. Os métodos modernos de produção originaram-se na indústria de algodão, não só na fiação e tecelagem, que empregavam trabalho "livre", mas também na colheita de algodão, que era o trabalho de escravos. Além disso, escravo algum jamais foi tão barato quanto as crianças miseráveis que as manufaturas de Lancashire empregavam em suas fábricas do início do século XIX, onde eram obrigadas a trabalhar, por pouco mais que alojamento e alimentação, 14 ou 16 horas por dia, até morrerem. (Deve-se recordar que a morte de um escravo era um prejuízo para seu dono, ao passo que a morte de um trabalhador assalariado não é.) Entretanto, os pioneiros da revolução industrial foram esses mesmos empregadores sem compaixão, pois suas cabeças eram melhores que seus corações. Sem inteligência, os homens nunca teriam aprendido a economizar trabalho manual por meio do auxílio de máquinas.

Não pretendo sugerir que a inteligência é algo que surge espontaneamente, de forma mística sem uma causa. Obviamente ela tem suas causas, e obviamente essas causas devem ser em parte buscadas no ambiente social. Mas, em parte, as causas são biológicas e individuais. Elas ainda são pouco compreendidas, embora o mendelianismo tenha dado o primeiro passo. Homens de habilidades superiores são definitiva e congenitamente tão diferentes da média quanto o são os débeis mentais. E, sem habilidades superiores, não poderiam ocorrer avanços fundamentais nos métodos de produção. 
Há uma escola moderna de sociologia, a qual professa ser mais estritamente científica que qualquer outra, e que é, pelo menos em alguma medida, um produto das doutrinas de Marx. Segundo essa escola, a sociologia só pode tornar-se verdadeiramente científica pela observação dos homens como coletividades em vez de como indivíduos, e pela observação apenas de seu comportamento físico, sem qualquer tentativa de interpretação psicológica. Até certo ponto, há muito a ser dito em favor dessa escola. Decerto o gosto pelo drama levou tanto leitores quanto escritores a depositar importância excessiva nos indivíduos; por certo, também, há um elemento de risco em qualquer interpretação psicológica do comportamento físico. Como diz o poeta:

Eu lhe perdoo por fingir que me ama,

Mas por que você me chutou escada abaixo? ${ }^{12}$

A escola em questão notará apenas o pontapé, e não inquirirá se este foi causado por amor dissimulado ou raiva. De qualquer forma podemos concordar, até aqui, que é uma coisa boa recordar os fatos indubitáveis a respeito de comportamentos manifestos antes de embarcar nos mares dubitáveis da motivação interior.

Um livro como "Middletown"13, embora seus autores não concordem com a teoria que estamos examinando, é um livro que os defensores dessa teoria podem aprovar, e mostra que muito trabalho valioso pode ser sugerido por ela. Cerca de 50 anos atrás, "Life and Labour of People in London", de Charles Booth, realizou, em uma escala muito maior, o mesmo tipo de serviço para Londres; foi um livro de imenso valor, que inspirou reformas que elevaram grandemente o bem-estar das camadas mais pobres da população em Londres. Ao reformador, para que venha a agir com sabedoria, tais pesquisas acerca das vidas habituais de homens, mulheres e crianças são imensuravelmente úteis.

Elas são, contudo, um meio, e não um fim em si mesmas; quando consideradas como um fim, estão sob risco de perder sua utilidade. Para começar, a objeção às interpretações psicológicas é tola. Por que nos opomos à pobreza e à moléstia? Porque elas causam sofrimento, que é um fenômeno mental. Para a observação puramente externa, pobreza e moléstia devem ser exatamente tão satisfatórias quanto prosperidade e boa saúde. Quando o astrônomo observa as estrelas, ele não tem que considerar se a condição delas é "boa" ou "má", porque ele não acredita que tenham a capacidade de sentir; mas seres humanos são diferentes, e uma sociologia que ignora seus sentimentos está omitindo o que é mais essencial. Não desejamos reformar o sistema solar, mas desejamos reformar o sistema social caso tenhamos alguma consideração para com o sofrimento. E somente considerações psicológicas podem mostrar-nos quais reformas são desejáveis.

De um ponto de vista puramente científico, a teoria me parece equivocada em minimizar o efeito individual. Frequentemente ocorre grandes forças sociais antagônicas encontrarem-se em equilíbrio momentâneo aproximado, e uma força comparativamente pequena poder decidir qual delas será vitoriosa, tal qual uma força muito pequena numa bacia hidrográfica pode decidir se a água fluirá para o Atlântico ou para o Pacífico. A Revolução Russa teria sido muito diferente sem Lênin, e foi uma força muito pequena que determinou aos alemães permitirem seu retorno à Rússia. Duque de Wellington comentou sobre a batalha de Waterloo: "Foi algo terrivelmente equilibrado. Acredito que não teríamos ganhado se eu não estivesse

\footnotetext{
12“It was all very well to dissemble your love,/But why did you kick me downstairs?”. Segundo o The Oxford Dictionary of Quotations (1992, p. 114), este verso popular em língua inglesa é de Isaac Bickerstaffe (1733-1808), dramaturgo irlandês, presente em "An Expostulation" (1789). Não confundir com Isaac Bickerstaff, pseudônimo de Jonathan Swift. (N. T.)

${ }^{13} \mathrm{Cf}$. a primeira parte desta tradução, página 6, nota 5, no Volume anterior. (N. T.)
} 
lá."14 Provavelmente ele estava certo. Tais exemplos mostram que o curso principal de grandes acontecimentos pode às vezes depender das ações de um indivíduo.

Isso, evidentemente, é deplorável do ponto de vista daqueles que estão impacientes para transformar a história numa ciência. Mas, de fato, embora alguns aspectos da história possam se tornar mais ou menos científicos, e embora seja importante fazê-lo tanto quanto for possível, o tema é muito complexo para ser reduzido a leis científicas no presente, e provavelmente o será nos próximos séculos. Há muito que, devido à nossa ignorância, parece fortuito, e demasiada probabilidade de interferência de forças incalculáveis. Não há nada genuinamente científico em um esforço prematuro para parecer científico.

Isto me leva a outro setor da história, a saber, a história da cultura, concebida em seu sentido mais amplo, a incluir religião, arte, filosofia e ciência. Este é um assunto fascinante quanto tratado sem a solenidade e tapeação em que foi mergulhado por professores pedantes. A visão oficial - que todo estudante deve adotar se almeja tirar boas notas - é aquela de acordo com a qual certos homens foram grandes e bons, e não devem de modo algum ser criticados, enquanto certos outros eram inteligentes porém equivocados, e cometeram erros estúpidos que são óbvios a qualquer criança. Já outros, que a um olhar imparcial mostram-se longes de desconsideração, não devem nunca ser mencionados, porque suas ideias são chocantes. Mesmo aqueles que são dignos do mais alto elogio devem ser tão mal interpretados a fim de se tornarem simplificados e razoáveis a pessoas comuns, cuja tarefa é elogiá-los. Acima de tudo, nenhuma ideia que possa provocar um mínimo de desconforto momentâneo à sensível meia-idade deve ser aceita.

Nem tão grandiosos devem os homens ser concebidos, nem, igualmente, o monumento a lhes ser erigido em nosso pensamento. $\mathrm{O}$ pedante, convencido de que sozinho possui toda a sabedoria, e confortável na segurança de seu cargo, elogia os homens que ele finge estudar, dissimulando que estes concordam com ele, e, especialmente, promove qualquer tipo de sentença ocasional insensata que se possam ter permitido. Ele está convencido de que os verdadeiramente grandes são sempre "serenos"; que eles veem, de forma misteriosa, como o bem provém do mal e que, geralmente falando, ajudam as pessoas a suportar com firmeza de espírito seus infortúnios. Jovens incautos, expostos a esse espantalho em quase toda universidade do mundo, tendem a rejeitar com escárnio todos os grandes nomes convencionais. Tomemos, por exemplo, Shakespeare, cuja suposta "serenidade" é tema de intermináveis disparates acadêmicos. Eis alguns exemplos de sua "serenidade":

Assim que nós nascemos, choramos por nos vermos

Neste imenso palco de loucos. ${ }^{15}$

Novamente:

Somos para os deuses o que as moscas são para os meninos:

Matam-nos só por brincadeira. ${ }^{16}$

Novamente:

A falar me ensinastes, em verdade. Minha vantagem nisso,

É ter ficado sabendo como amaldiçoar. ${ }^{17}$

E, bem conhecido como é, eu não poderia omitir o grande discurso em Macbeth:

Amanhã, e amanhã, e ainda outro amanhã

\footnotetext{
14 “It was a damned nice thing. I do believe if I had not been there we should not have won." Nesta expressão de Wellington o termo nice carrega o sentido "arcaico" de incerto ou equilibrado, não de bom ou agradável. (N. T.)

${ }^{15}$ King Lear, Ato IV, Cena VI. SHAKESPEARE, William. O Rei Lear. Trad. Millôr Fernandes. Porto Alegre: L\&PM, 2009. p. 114. (N. T.)

${ }^{16}$ King Lear, Ato IV, Cena I. Ibid., p. 96. (N. T.)

${ }^{17}$ The Tempest, A to I, Cena II. SHAKESPEARE, William. Comédias. Trad. Carlos Alberto Nunes. São Paulo: Edições Melhoramentos, 1959. p. 44. (N. T.)
} 
Arrastam-se nessa passada trivial do dia para a noite,

Da noite para o dia, até a última sílaba do registro dos tempos.

E todos os nossos ontens não fizeram mais que iluminar para os tolos

O caminho que leva ao pó da morte. Apaga-te, apaga-te, chama breve!

A vida não passa de uma sombra que caminha, um pobre ator

Que se pavoneia e se aflige sobre o palco - faz isso por uma hora

E, depois, não se escuta mais sua voz. É uma história

Contada por um idiota, cheia de som e fúria

E vazia de significado. ${ }^{18}$

Não, os maiores homens não foram "serenos". Eles tinham, a bem da verdade, uma coragem última, um poder de criar beleza onde a natureza só colocara horror, o qual pode, a uma mente pequena, assemelhar-se à serenidade. Mas sua coragem tinha de superar a dos homens comuns, porquanto eles enxergaram mais profundamente a indiferença da natureza e a crueldade do homem. Camuflar essas coisas em mentiras confortáveis é a atitude dos covardes; a atitude dos grandes homens é vê-las com inexorável clareza e, ainda assim, pensar e sentir nobremente. E, na medida em que podemos ser todos grandiosos, essa é a atitude de cada um de nós.

Mas tudo isso, o leitor pode sentir, é uma digressão da história da cultura. Eu não concordo. Na história da cultura, o material é vasto, e é necessário seleção. Esta deve ser guiada, pelo menos em parte, por um senso de valores: devemos dispor de algum critério pelo qual decidir quem merece ser recordado. Este não deve, é verdade, ser nosso único princípio de escolha; alguns indivíduos merecem ser estudados graças à sua influência. Mesmo se não tivermos Maomé em alto apreço, não podemos ignorá-lo, porque grande parte da humanidade acredita nele. Todavia, mesmo assim, padrões são necessários para que a história da cultura venha a ser estudada com algum proveito; não devemos admirar indiscriminadamente quem quer que fora influente, pois, se o fizermos, podemos encontrar-nos adorando a Satanás. O valor essencial da cultura é sugerir padrões de bem e mal que a ciência por si mesma não consegue fornecer, e isso deve lembrado em todo o nosso estudo da cultura do passado e do presente.

Para mim, na condição de alguém cuja vida foi acima de tudo devotada à especulação filosófica, a parte mais interessante da história da cultura é a história da filosofia, particularmente em sua relação com a religião. A filosofia começou entre os gregos como uma rebelião contra a religião, incorporando o ceticismo de homens que, no curso do comércio, foram postos em contato com muitas crenças e costumes, e por essa razão passaram a exigir algo mais do que tradição tribal como apoio para seu próprio credo. Seu racionalismo era, evidentemente, imperfeito; mesmo o maior livre-pensador entre eles conservou a fé no Destino ou na justiça cósmica de que falamos anteriormente. ${ }^{19}$ Mas sua racionalidade, onde esta existira, foi mais surpreendente do que sua irracionalidade onde esta subsistira. Eles repudiaram os deuses olímpicos, formularam a concepção de causalidade universal, e tentaram descobrir meios pelos quais o universo existente poderia ter evoluído de acordo com leis naturais. Pela primeira vez na história humana, a Razão foi declarada soberana, e todas as coisas, se não de fato, pelo menos em princípio, foram submetidas a seu escrutínio. Preconceitos remanescentes sobreviveram porque não foram notados; se alguém houvesse assinalado que eram preconceitos, os primeiros filósofos jônicos tê-los-iam abandonado.

A despeito disso, a filosofia grega não permaneceu à altura deste brilhante início; havia uma serpente no paraíso filosófico, e seu nome era Pitágoras. A religião órfica, que tinha características reencarnacionistas, já havia conquistado muitos racionalistas

\footnotetext{
${ }^{18}$ Macbeth, Ato V, Cena V. SHAKESPEARE, William. Macbeth. Trad. Beatriz Viégas-Faria. Porto Alegre: L\&PM, 2008. p. 124. (N. T.)

${ }^{19}$ Cf. a primeira parte desta tradução no Volume anterior, p. 7. (N. T.)
} 
gregos, e uma espécie de orfismo foi introduzida na filosofia por Pitágoras, a qual deixou de ser uma tentativa honesta de compreender o mundo e tornou-se uma busca pela salvação através da intoxicação. ${ }^{20} \mathrm{O}$ orfismo era uma ramificação do culto de Baco, que, no entanto, procurou substituir a intoxicação verdadeiramente alcóolica do culto original por uma intoxicação espiritual. Daqueles tempos até hoje, continua-se a pensar que há algo divino em torno da loucura, desde que esta possua a qualidade da intoxicação espiritual; uma visão inteiramente sóbria do mundo vem sendo tida como exemplar de uma mente rasteira e exígua. De Pitágoras esta perspectiva passou para Platão, de Platão para os teólogos cristãos, destes, sob nova forma, a Rousseau e os românticos e à miríade de semeadores de bobagens que florescem onde quer que homens e mulheres estejam fartos da verdade.

Há em nossos dias, todavia, um poderoso antídoto contra a idiotia, o qual era escasso em tempos passados - refiro-me à ciência. A ciência não pode ser menosprezada ou negada, porque ela está fundida à técnica moderna; ela é fundamental tanto à prosperidade na paz quanto à vitória na guerra. De um ponto de vista intelectual, esse é, provavelmente, o aspecto mais promissor de nossa era, e o único capaz de tornar possível que nos livremos da total submersão em novas e antigas superstições.

Um dos estudos mais fascinantes na história da cultura é o desenvolvimento gradual da doutrina católica, que foi concluída no século XIII. Na Igreja à época da queda do Império Romano do Ocidente (i.e., no século V) havia elementos provenientes de três fontes: judaica, grega e romana. A Igreja adquiriu dos judeus seus livros e histórias sagrados, a crença em um Messias (que os cristãos, mas não os judeus, acreditavam já ter vindo), a moralidade um tanto atroz e a intolerância para com todas as religiões, salvo a sua. A componente helênica apareceu em especial na esfera do dogma. São João, São Paulo e os Padres aos poucos construíram, mediante adaptações da filosofia grega, uma elaborada teologia, completamente alheia ao espírito judeu. O Evangelho de São João, ao contrário do de Mateus, Marcos e Lucas, dá mostra dos estágios iniciais da filosofia helenística cristã. Os Padres, especialmente Orígenes e Santo Agostinho, fizeram do platonismo parte integral do pensamento cristão; é surpreendente a quantidade de doutrina essencialmente cristã que Santo Agostinho confessa ter encontrado em Platão. Tão logo o Império se fez cristão, os bispos adquiriram funções administrativa e judicial; os concílios ecumênicos promovidos pelos imperadores propiciaram a gênese de uma autoridade central, embora inicialmente apenas em matéria doutrinal. Sem a força oriunda dos métodos governamentais de Roma, é duvidoso se a Igreja poderia ter sobrevivido ao cataclismo das invasões bárbaras.

Nos séculos que se seguiram, ela, ainda que de modo imperfeito, representava a cultura mediterrânea, enquanto a aristocracia leiga representava os bárbaros do norte. A Igreja, em alguns momentos, por pouco não perdera sua característica distintiva, e quase se tornara parte e parcela do sistema feudal. Isso foi evitado, no entanto, pelo aumento gradativo do poder do Papa, e pela insistência papal no celibato clerical, a qual impediu a transmissão das terras eclesiásticas de pai para filho. Do início do século XI ao fim do século XIII, a Igreja rapidamente cresceu em poder, disciplina e erudição; a este último respeito, os católicos ainda se curvam à autoridade de São Tomás de Aquino, cuja palavra, em todas as questões filosóficas, é lei em todas as instituições educacionais católicas. Contudo, Aquino foi um inovador audacioso em sua época. A influência dos árabes levou-o a preferir Aristóteles a Platão, e por conta disso ele foi condenado pelas universidades de Paris e Oxford. Esta oposição a Aquino e a Aristóteles (que também foi condenado) foi esquecida, e Aristóteles é

\footnotetext{
${ }^{20}$ Intoxicação no sentido de busca por um estado catártico ou de purificação da alma, i.e., a intoxicação do espírito por objetos de natureza essencialmente intelectual (o número, por exemplo), idênticos em substância à natureza mesma da alma. (N. T.)
} 
agora considerado pelos católicos quase como se fosse um dos Padres. Talvez seja permitido - embora a contragosto - questionar a eficácia de sua cura para a insônia em elefantes ${ }^{21}$, mas seus erros na doutrina do silogismo não devem ser reconhecidos. Por esta razão, a lógica moderna é território proibido para os católicos.

Tão grandes foram os infortúnios da Igreja nos séculos XIV, XV e XVI que sua sobrevivência pode quase ser reivindicada como um milagre. Primeiro veio o Grande Cisma, durante o qual dois sujeitos reclamavam ser o Papa. Ninguém sabia qual deles era o Papa verdadeiro; cada um proclamou o outro excomungado. Só uma dessas excomunhões era válida, porém qual? Quem entre os dois fosse o verdadeiro Papa devia, naturalmente, estar certo em declarar o outro um embusteiro, mas ninguém sabia qual era o Santo Padre e qual era um impostor descarado. A situação era embaraçosa, e um tremendo fator de escândalo. Quando finalmente o Cisma foi superado, a Renascença começou, e os Papas deixaram de lado os interesses da Igreja em jogar o jogo de poder da política italiana e concorrer para ampliar seus domínios seculares. Uma série de livres pensadores leigos e Papas licenciosos, que taxavam a fé em todo o mundo católico a fim de manterem o próprio luxo, de tal forma escandalizou a religiosidade do Norte que por fim se produziu a Reforma.

No início a Reforma arrastou consigo tudo que encontrou pelo caminho na maioria dos países ao norte dos Alpes. Mas a causa católica foi salva por Loyola, Carlos V e pelos Fuggers. Loyola fundou a Ordem Jesuíta, a qual, por meio de zelo, engenho e educação, salvaguardou o poder. Carlos V tratou de reunir sob seu controle o Império, a Espanha e os Países Baixos. A rica casa bancária dos Fuggers já lhe havia emprestado tanto dinheiro que seu êxito tornou-se vital para eles; estes, portanto, o apoiaram com todos os seus recursos, fazendo-o financeiramente superior a seus rivais. No final foram à bancarrota por causa de empréstimos aos Habsburgos, mas por volta dessa época a Igreja já estava a salvo.

Dá a história passada da Igreja alguma base para a previsão de seu futuro? Seus infortúnios não cessaram no século XVI. As guerras do século XVIII e a subsequente expansão dos Estados Unidos deram aos protestantes influência sobre todo o continente americano acima da fronteira com o México. A França foi veementemente anticlerical durante a Revolução e mais uma vez na época da reabilitação de Dreyfus. A Revolução Russa foi anticristã, e os nazistas fizeram tudo a seu alcance para destruir a influência da Igreja na Alemanha. Não obstante, os católicos têm motivos de sobra para acreditar no futuro. Napoleão achou conveniente fazer as pazes com o Papa, e Napoleão III, até sua queda, preservou o poder temporal em Roma graças a guarnições francesas. Como será a França do pós-guerra é-nos impossível saber; atualmente, no entanto, os líderes de todos os partidos são católicos devotos. O governo russo pôs fim à hostilidade contra a religião e irá, sem dúvida - a fim de agradar a seus aliados -, mais longe nessa nova direção. Na Alemanha, quando os nazistas caírem, haverá risco de caos, e a Igreja Católica será uma das poucas forças trabalhando pela estabilidade. Nos Estados Unidos, os católicos já são suficientemente fortes a ponto de controlar a educação em Nova Iorque ${ }^{22}$ e Boston, e conseguiram fazer o Departamento de Estado ser favorável a Franco durante a Guerra Civil Espanhola. Eles convertem muita gente, e fazem muitos mais filhos que os protestantes. Estatísticas mostram que, a menos que novos fatores entrem em cena, os católicos serão maioria nos Estados Unidos em aproximadamente 50 anos. Por isso há toda a razão para esperar que seu poder,

\footnotetext{
${ }^{21}$ Em Da História dos Animais, livro VII, 605b, Aristóteles recomenda que se esfreguem os ombros de elefantes que sofrem de insônia com sal, azeite e água quente. (N. T.)

${ }^{22}$ É impossível não ver aqui uma menção autobiográfica. Após lecionar na Universidade da Califórnia, em 1940 Bertrand Russell foi convidado a atuar como professor no City College, em Nova York. Devido às suas opiniões controversas, o filós ofo foi acusado de imoralidade, e uma decisão do juiz católico John E. McGeehan cancelou a nomeação da universidade estadual. O caso gerou repercussão mundial e John Dewey, Albert Einstein e Charlie Chaplin estavam entre seus defensores. (N. T.)
} 
no final deste século, será maior do que o foi em qualquer época desde a Revolução Francesa. De minha parte, vejo com preocupação esta possibilidade.

Refletir sobre a Igreja naturalmente sugere um setor da história que, em minha opinião, foi muito pouco estudado; quero dizer, a história das organizações. Uma organização tem vida própria, e atravessa fases de juventude, maturidade e velhice, analogamente às fases na vida de um indivíduo. Acredito que pelo estudo das organizações poder-se-ia chegar a pensamentos muito úteis - não a generalizações infalíveis. Há organizações de tipos muito diferentes: igrejas, partidos políticos, instituições de ensino, corporações financeiras, sindicatos e assim por diante. Houve, em todas as eras de progresso técnico, um aumento das organizações, e isto é especialmente verdade em nossa própria época. O número de coisas que um indivíduo faz sozinho por iniciativa própria está diminuindo continuamente, e o número de coisas para as quais ele depende de alguma organização está continuamente aumentando. Se você é um cidadão médio, você nasce em um hospital e é educado pelo Estado; você ganha a vida trabalhando para certa corporação; seu jornal, seu rádio, sua televisão são mantidos por grandes companhias; se você comprar uma casa, provavelmente pedirá emprestado o dinheiro da compra não a um indivíduo, mas a uma organização; quando morrer, uma companhia de seguros assistirá as necessidades da sua viúva. Como cidadão livre e independente de uma democracia, e com direito a voto, você tem direito, de tempos em tempos, de manifestar preferência entre dois indivíduos que lhe são apresentados por duas organizações chamadas partidos políticos, as quais juntas representam os interesses de políticos profissionais. Como alma imortal, você pode buscar salvação numa organização chamada igreja, que provavelmente possui direitos de propriedade sobre as condições de adesão a dogmas fixados há séculos; se nenhuma das igrejas disponíveis lhe satisfaz, seus vizinhos o verão, desconfiados, como um excêntrico, as esposas deles evitarão sua esposa, e sua carreira profissional será prejudicada. Do berço ao túmulo, e mesmo - se as igrejas estiverem certas - na próxima vida, você está nas mãos das organizações, as quais determinam o quanto lhe é permitido perseguir os próprios interesses.

Ora, cada uma dessas organizações tem um duplo propósito, um público e um privado. O Estado, quando o educa, tem como objetivo público fornecer-lhe conhecimento útil, e como objetivo privado torná-lo propício a pagar impostos em benefício de políticos corruptos. Seu jornal existe publicamente para dar notícias, privadamente para dá-las de uma forma tal que favoreça os interesses dos proprietários. Seu partido político tem um programa público, apresentado como sendo vantajoso à nação; mas se você não é jovem nem ingênuo, sabe que o partido, se vitorioso, provavelmente considera que o programa serviu a seu propósito, que foi assegurar dinheiro público para certo grupo de pessoas em vez de outro. Quanto às igrejas - mas, por favor, guardemos segredo! -, aqui devemos separar as coisas; nenhum dignitário eclesiástico, estou certo, jamais considera por um só instante qualquer outra coisa senão o bem-estar de sua congregação ${ }^{23}$.

O estudo da história das organizações revela que, devido à ignorância das leis do seu desenvolvimento, os esforços idealistas de muitos dos maiores e melhores homens da espécie perderam-se em caminhos que só se mostraram perniciosos. Tome-se, por exemplo, a Ordem Franciscana. Seria difícil encontrar em toda a história pessoa mais amável que São Francisco; ele amava com um amor espontâneo não somente toda a humanidade, mas animais ferozes e pássaros, o Sol, as estrelas e o vento; sua virtude era tão espontânea que ele estava sempre feliz. Sua fé, não há dúvida, era um tanto quanto impensada: ele fez uma longa e perigosa viagem para ver o sultão, que esperava converter ao cristianismo. Mas, em todo caso, a tentativa foi menos danosa

${ }^{23}$ Obviamente o autor apela à ironia. (N. T.) 
que o método igualmente inútil das Cruzadas. Ele fundou a Ordem Franciscana na esperança de espalhar seu próprio espírito de amor fraternal; acreditando que o egoísmo não deveria ter vez, adotou os votos tradicionais de castidade, pobreza e obediência. Seu sucessor imediato atolou-se em luxúrias e rebelou-se contra o Papa; seus seguidores tornaram-se guerreiros encarregados de mobilizar recrutas nas guerras selvagens entre guelfos e gibelinos, e, juntos com os dominicanos, dirigiram as infames perseguições da Inquisição. Durante certo tempo uma minoria de franciscanos, dos quais Guilherme de Ockham foi um dos últimos, permaneceu fiel ao espírito de seu fundador; mas depois do século XIV ficaria difícil apontar qualquer benefício que a humanidade deve à existência da Ordem.

Nada há de surpreendente nesse desenvolvimento; se o Santo tivesse tido mais sabedoria de vida, tê-lo-ia previsto. Sob a égide de um nome honrado são possíveis coisas abomináveis que, de outra forma, causariam terrível desgraça. Na mente de muitos japoneses piedosos, crimes em nome da nação são justificados em nome de Buda. É desnecessário falar dos incontáveis pogroms, perseguições e caça às bruxas que foram consagrados em nome de Cristo. Mais perto de nós, pode mencionar-se como o nome de Lincoln se tornou, na época corrupta que se seguiu à Guerra Civil, um escudo para proteger uma gangue de bandidos sem-vergonhas. Essas são todas reflexões pessimistas, mas não me contento em esboçar uma moral de indolente cinismo. Eis a moral correta: deve-se estudar a evolução das organizações com o fito de descobrir como evitar os males de que temos tratado.

Algumas organizações logram realizar seu objetivo original durante todo um longo período; outras malogram cedo. A Royal Society, fundada no século XVII para a promoção da ciência, continua desde então a incluir entre seus Fellows todos os melhores cientistas da Grã-Bretanha; por outro lado, a Royal Academy falhou patentemente em identificar os melhores pintores. Na França, similarmente, o Institut reconheceu adequadamente o mérito científico, enquanto a Academia excluiu a maioria dos melhores literatos. A razão é que, é evidente, o mérito científico é menos duvidoso que os méritos artístico e literário. A santidade é ainda mais difícil de reconhecer do que a excelência artística, pois ao longo das eras os santarrões levaram à perfeição a técnica do mimetismo ${ }^{24}$. Consequentemente, uma organização que só pode fazer o bem se seus líderes são santos com certeza começará a fazer o mal antes do tempo. Esta é uma verdade importante que os santos demoram a perceber.

Há três coisas a serem consideradas sobre uma organização: o que ela oferece ao público, o que ela oferece a seus membros comuns, e o que ela oferece a seus dirigentes. A última, na prática, prevalece muito mais frequentemente sobre as outras duas. Isto se aplica a muitas situações diferentes. Uma pessoa, digamos, coloca à venda o sabão mais refinado do mercado. Graças à hábil propaganda, ela faz com que o público acredite nela; então, ela vende sua invenção a uma companhia; o público descobre a fraude e a companhia vai à falência, mas o inventor do sabão continua com a sua fortuna. Quando eu era jovem, o costume era ditadores espoliarem o povo em certos países da América do Sul até provocarem uma revolução; depositavam o dinheiro no exterior e sempre contavam com um veloz navio a vapor a esperar-lhes no porto de suas capitais. Quando a revolução começava, voavam para Paris e a partir daí viviam felizes para sempre. Tais ditadores estão para a política tal como nosso fabricante de sabão está para os negócios. Mas aqueles homens não são tão malignos quanto os que lograram dar continuidade a seu poder. Qualquer organização, por mais idealistas que sejam seus objetivos declarados, pode degenerar em tirania, a menos que o público

\footnotetext{
${ }^{24}$ A expressão original é "protective imitation", conceito da biologia evolucionária, para cuja tradução escolheu-se o termo "mimetismo", já consagrado nos compêndios dessa disciplina. O fenômeno do mimetismo ocorre quando uma espécie possui características que evoluíram, como vantagem adaptativa, para assemelhar-se às de outras espécies, por exemplo, o caso da falsa cobra-coral e da verdadeira cobra-coral. (N. T.)
} 
conserve firmemente em suas próprias mãos algum meio efetivo de controle sobre os líderes. A democracia é o único meio até agora conhecido, mas ela não será um meio completamente eficiente até que tenha sido aberta e estendida a regiões econômicas das quais ainda está excluída. Os dados essenciais sobre a totalidade deste assunto só podem ser obtidos a partir de um estudo da história.

A questão se um governo mundial - se estabelecido - poderia ser estável é tal que pertence à ciência das organizações, uma questão, portanto, a respeito de qual história se poderia esperar que lançasse luz. Seria falacioso argumentar, como fazem alguns estudantes de história, que o que nunca aconteceu jamais acontecerá. Ciro, no século VI a.C., estabeleceu um império de dimensões sem precedentes e conseguiu mantê-lo unido graças à criação de excelentes estradas. O Império Romano, que era ainda maior, só se tornou possível graças a estradas ainda melhores. É óbvio que a aeronave tem, num grau muito mais elevado que as estradas romanas, o mesmo efeito de tornar possível um Estado maior. É razoável, por conseguinte, esperar que ela facilite a criação de novas formas políticas, e, em particular, que possibilite a um Estado mundial ser estável se este detivesse o monopólio do controle do espaço aéreo. Há sérios obstáculos à criação de um Estado global, mas não penso que seria difícil mantê-lo se tal um dia existir.

A questão de combinar disciplina com liberdade nas melhores proporções é tal que nossa época deve resolver, e resolver rapidamente, para que se possam evitar os perigos opostos da anarquia e da ditadura, os quais têm, desde o surgimento da Grécia, oscilado neste ponto tanto para cima quanto para baixo. No entanto, uma gangorra sem fim certamente não é o melhor que a inteligência humana pode compreender. O que houve até o momento foi algo do tipo: uma cultura ou nação, sob um rígido sistema tradicional, acumula uma energia reprimida que finalmente quebra os laços que a unia. Velhos hábitos ruem primeiramente na esfera da opinião e, a seguir, na esfera da conduta. As eras mais criativas são aquelas nas quais a opinião é livre, mas o comportamento ainda de certo modo convencional. Por fim, entretanto, o ceticismo demole tabus morais, a sociedade se torna insuportavelmente anárquica, a liberdade é substituída pela tirania, e uma nova tradição mais sólida aos poucos toma forma. Na Grécia, os heróis homéricos têm um padrão imutável de comportamento e um código moral que nem mesmo os transgressores questionam. Em Ésquilo a velha rigidez, um tanto suavizada, ainda existe, mas os sofistas produziram dúvidas, e Eurípedes é perplexo e hesitante. O resultado, após um período de extraordinário esplendor, foi uma decadência geral, primeiro da moral, e depois de outras formas de virtude. Os severos romanos impuseram seu jugo, mas, por sua vez, primeiro se tornaram inteligentes e em seguida brandos. $\mathrm{O}$ cristianismo, mais austero que qualquer religião anterior, novamente criou um sistema em que as energias da comunidade foram cultivadas, mas o indivíduo oprimido. Na Itália renascentista a disciplina cristã colapsou, para ser substituída por um breve período de gênio e individualismo - logo extinto pelos espanhóis e pela Contrarreforma. Analogamente, o movimento romântico conduziu às ditaduras do nosso tempo. Os países de língua inglesa, deve-se dizê-lo, têm estado menos sujeitos a essas oscilações do que os do continente europeu.

A solução do dilema entre liberdade e disciplina deve, evidentemente, ser buscada em um acordo. Não podemos admirar um sistema social que não dá margem à liberdade individual, tampouco podemos aprovar um em que o individualismo excessivo torne instável o sistema social. Alguém poderia argumentar que há uma oposição fundamental entre inteligência e moralidade, que apenas a ignorância e a superstição tornam bom o homem, e que uma pessoa intelectualmente emancipada será inevitável e completamente egoísta. Essa é, todavia, uma teoria obscurantista que sustenta uma visão errada acerca tanto da moralidade quanto da inteligência. Se no ensino dos jovens a moralidade genuína for completamente confundida com a 
supersticiosa, poderá ser-lhes difícil distinguir as duas. Se lhe ensinaram que xingar é tão errado quanto roubar, você pode, quando decidir que é permitido xingar, concluir que não há mal algum em roubar, mas isso só mostraria que você não é inteligente e que lhe ensinaram uma moral estúpida. A verdadeira moral é tal que a inteligência não pode debilitá-la, tampouco a inteligência necessariamente encoraja o egoísmo. Isso só ocorre quando o altruísmo foi ensinado pelas razões erradas, e só então após tanto tempo que seu alcance tornou-se limitado. A este respeito, a ciência é um elemento útil na cultura, por ter uma estabilidade que a inteligência não pode abalar, e que cria um hábito mental impessoal que a faz aceitar como natural uma ética social em vez de uma puramente individual. Mas a história talvez seja um antídoto ainda melhor contra o individualismo anárquico, bem como contra um tradicionalismo gélido.

Algumas sociedades pereceram por excesso de individualismo e ceticismo; disso a Grécia e a Itália renascentista são os exemplos principais. Estas, antes do perecimento, produziram uma grande explosão de genialidade, com a qual o mundo lucrou desde então. Elas fizeram muito mais pela humanidade do que fariam se tivessem sobrevivido em respeitabilidade estéril. E o meio pelo qual pereceram não é o mais comum: o meio mais comum é afundar-se no conservadorismo, atemorizado pelo que sucedera, aterrorizado pelo que sucederá, completamente estereotipado em palavras e ações. Muitas outras nações foram levadas à destruição pelo medo da mudança do que pelo amor a ela. Nenhuma nação pode florescer por muito tempo a menos que tolere indivíduos excepcionais, cujo comportamento não é exatamente como aquele da vizinhança. Todos sabem que indivíduos que realizam grandes feitos nas artes, na literatura ou na ciência tendem, quando jovens, a ser excêntricos. Quando a excentricidade não é tolerada na mocidade, haverá poucas realizações de grande valor entre homens e mulheres adultos. Mas embora se saiba dessas coisas, é difícil incorporá-las à prática da educação. É certo que as pessoas devam viver com alguma referência à comunidade, e com alguma esperança de serem úteis a ela, mas isso não significa que todas devam ser iguais, pois tarefas excepcionais exigem características excepcionais.

Até agora falei sobre várias maneiras pelas quais a história pode ser interessante e instrutiva, mas, além destas, ela possui uma função mais geral, mais importante talvez do que qualquer uma delas. Nossa vida corporal está limitada a uma pequena porção do tempo e do espaço, mas nossa vida mental não precisa ser limitada assim. O que a astronomia faz para ampliar o habitat espacial da mente, a história o faz para expandir seu domínio temporal. Nossa vida particular é amiúde aborrecedora, e algumas vezes quase intoleravelmente dolorosa. Vê-la em perspectiva, como um fragmento infinitesimal na vida da humanidade, torna um pouco menos difícil suportar os males pessoais que não podem ser evitados. Apesar de a história ser cheia de altos e baixos, há uma tendência geral em que é possível notar certo contentamento; sabemos mais do que nossos ancestrais sabiam, temos mais controle sobre as forças da natureza, morremos menos de moléstias e de cataclismos naturais. É verdade que ainda não aprendemos a nos proteger de nós mesmos: o homem é tão perigoso ao homem como ele sempre foi. Mas mesmo nesse caso há pelo menos sinais pregressos de melhora. A violência agora é em sua maior parte organizada e governamental, e é mais fácil imaginar formas de acabar com ela do que com a violência ocasional não planejada de épocas mais primitivas.

A perspectiva histórica nos capacita a ver com mais clareza quais eventos e quais tipos de atividades têm importância permanente. A maioria dos contemporâneos de Galileu viu muito mais importância na Guerra dos Trinta Anos do que nas suas descobertas, mas é evidente para nós que tal guerra não passou de 30 anos de futilidade, ao passo que suas descobertas deram início a uma nova era. Quando Gladstone visitou Darwin, este comentou mais tarde: "Que honra ser visitado por tão grande homem." Sua modéstia era cordial, mas revelava falta de perspectiva histórica. 
Muitos acontecimentos - as disputas entre partidos, por exemplo - despertavam no momento uma excitação absolutamente fora da proporção de sua real importância, enquanto que os grandes eventos, tais como os cumes das altas montanhas, embora dominantes de muito longe, são vistos em primeiro plano muito de perto. É uma ajuda em direção à sanidade e ao julgamento sereno adquirir o hábito de enxergar os eventos contemporâneos em sua situação histórica, e de imaginá-los como eles aparecerão quando estiverem no passado. Os teólogos nos garantem que Deus vê o tempo como um todo como se este fosse presente; não está ao alcance humano fazer isto exceto em um grau muito limitado, mas na medida em que possamos fazê-lo, trata-se de uma ajuda em direção à sabedoria e à intuição contemplativa. Vivemos no presente, e no presente devemos agir; mas a vida não é só ação, e a ação é melhor quando procede de uma ampla reflexão na qual o presente perde o lampejo de sua persistência emocional. Os homens nascem e morrem; alguns dificilmente deixam rastros, outros transmitem alguma coisa boa ou má às gerações futuras. O homem cujos pensamentos e sentimentos são engrandecidos pela história desejará ser um transmissor, e transmitir, até onde puder, o que seus herdeiros julgarão que fora bom.

Endereço para correspondência: Ernane São João Garcia, Universidade Federal de São Carlos, Rodovia Washington Luís, Km 235, s/n, Jardim Guanabara, 13565-905, São Carlos, SP, Brasil. e-mail: ernanegarcia@gmail.com Conflito de interesses: Nenhum.

Todos os autores leram e aprovam a versão final submetida a revista Em curso. 